\title{
Budidaya Lamtoro Sebagai Bank Pakan Sumber Protein di Kecamatan Moyo Utara Kabupaten Sumbawa
}

\author{
Oscar Yanuarianto*, Muhamad Amin, Syamsul Hidayat Dilaga, Dahlanuddin
}

Fakultas Peternakan, Universitas Mataram, Mataram, Indonesia

\author{
Article history \\ Received: 09-02-2021 \\ Revised: 04-03-2021 \\ Accepted: 14-03-2021 \\ *Corresponding Author: \\ Oscar Yanuarianto, \\ Fakultas Peternakan, \\ Universitas Mataram, Mataram, \\ Indonesia;
}

Email: oscary338@gmail.com
Abstract: Currently, the Lamtoro plant has become the prima donna of forage for ruminants in NTB Province. This plant is able to grow in relatively dry land and can be a source of protein for ruminants, maintenance and maintenance is relatively easy because it does not require a lot of water. On the other hand, the use of lamtoro as a source of protein for ruminant feed is an efficient step in meeting animal feed needs. Through the utilization of lamtoro, the use of less productive land can be utilized as well as a reforestation tree to prevent erosion, on the other hand, the use of lamtoro can increase farmers' income because the cost of foraging for food in the dry season can be minimized, the quality of feed given to livestock is maintained so that livestock productivity is maintained. The dry season remains high, therefore the Maju Bersama Group in the Filter Village of North Moyo District as one of the livestock groups in North Moyo District where the population does a lot of raising ruminant livestock, it is deemed necessary to carry out community empowerment service activities through counseling on "Lamtoro Cultivation As a Protein Source Feed Bank in North Moyo District, Sumbawa Regency. " Providing counseling in the form of demonstrations, speeches (lectures and questions and answers), and distribution of leaflets attended by 20 participants including members of farmer groups and local residents. The results of the counseling were considered very useful. This could be seen from the enthusiasm of the extension participants who attended both the question and answer session and the demonstration session.

Keywords: Lamtoro; Protein Feed Bank; North Moyo; Sumbawa Regency

Abtrak: Tanaman Lamtoro saat ini telah menjadi primadona hijauan pakan ternak ruminansia di Provinsi NTB. Tanaman ini mampu tumbuh di lahan yang relatif kering dan dapat sebagai sumber protein untuk ternak ruminansia, perawatan dan pemeliharaannya relatif mudah karena tidak membutuhkan banyak air. Di sisi lain, pemanfaatan lamtoro sebagai sumber protein untuk pakan ruminansia merupakan langkah efisiensi dalam pemenuhan kebutuhan pakan ternak. Melalui pemanfaatan lamtoro tersebut, pemanfaatan lahan yang kurang produktif dapat termanfaatkan sekaligus sebagai pohon penghijauan untuk mencegah erosi, disisi lain pemanfaatan lamtoro dapat meningkatkan pendapatan petani karena biaya mencari pakan pada musim kemarau dapat diminimalisir, kualitas pakan yang diberikan pada ternak tetap terjaga sehingga produktifitas ternak pada musim kemarau tetap tinggi, oleh karena itu Kelompok Maju Bersama di Desa Penyaring Kecamatan Moyo Utara sebagai salah satu kelompok ternak di Kecamatan Moyo Utara yang penduduknya banyak melakukan kegiatan memelihara ternak ruminansia, dipandang perlu untuk dilakukan kegiatan pengabdian pemberdayaan masyarakat melalui penyuluhan tentang "Budidaya Lamtoro Sebagai Bank Pakan Sumber Protein Di Kecamatan Moyo Utara Kabupaten Sumbawa." Pemberian penyuluhan dalam bentuk 
demonstrasi, orasi (ceramah dan tanya jawab), dan penyebaran leaflet yang diikuti oleh 20 orang peserta yang meliputi anggota kelompok peternak dan warga sekitar. Hasil penyuluhan dirasa sangat bermanfaat hal ini dapat dilihat dari antusiasnya peserta penyuluhan yang hadir baik pada sesi tanya jawab maupun sesi demonstrasi.

Kata Kunci: Lamtoro; Bank Pakan Protein; Moyo Utara; Kabupaten Sumbawa

\section{PENDAHULUAN}

Peternakan merupakan salah satu sektor unggulan di NTB. Tersedianya areal padang penggembalaan memungkinkan penggembalaan ternak bebas mendominasi sistem peternakan di NTB. Namun, saat ini daya dukung lahan semakin terbatas, terlebih pada musim kemarau. Untuk memaksimalkan daya dukung lahan di musim kemarau maka pemanfaatan lahan kurang produktif dapat digunakan sebagai areal penanaman sekaligus sebagai upaya penghijauan kembali lahan-lahan yang gundul atau kurang produktif yang pada akhirnya diharapkan dapat menghijaukan kembali areal tersebut dan sekaligus sebagai bank pakan bagi ternak ruminansia pada saat musim kemarau.

Di Kabupaten Sumbawa hampir seluruh lahan pertanian, terutama ladang umumnya digunakan sebagai lahan untuk menanam jagung. Beberapa tahun terakhir, warga Kabupaten Sumbawa gencar melakukan budidaya tanaman jagung. Dampak dari aktifitas ini, pembukaan lahan menjadi areal pertanian hampir tidak terkendali, sehingga hutan-hutan lindung yang ada hampir seluruhnya berubah fungsi. Dampak dari aktifitas ini menyebabkan ketersediaan air tanah pada saat tertentu menjadi sangat berkurang yang berdampak pada tanaman dan ternak yang hidup diatasnya. Pada musim kemarau ketersedian pakan sangat dirasa kurang, sehingga peternak harus mengambil pakan jauh dari tempat tinggalnya dan relatif pakan yang diperoleh berupa limbah pertanian berupa jerami baik itu jerami padi maupun jerami jangung. Kedua jenis limbah ini mempunyai kualitas yang kurang baik sebagai pakan ternak sehingga berpengaruh terhadap performan dan produktifitas ternak yang mengkonsumsinya.

Di sisi lain, pemanfaatan lamtoro sebagai pakan ternak di Kabupaten Sumbawa khususnya kecamatan Moyo Utara masih sangat minim dilakukan karena keterbatasan pengetahuan peternak tentang manfaat dan tata cara budi daya lamtoro.

Lamtoro taramba adalah salah satu jenis tanaman lamtoro yang adaptif dengan lingkungan dan hasilnya bisa memenuhi protein yang cukup bagus untuk ternak sapi (Dilaga dkk., 2016). Lebih lanjut Dahlanuddin (2013) menyatakan bahwa, pemberian 100\% lamtoro dalam bentuk kering dapat meningkatkan kenaikan berat badan harian $0,47 \mathrm{~kg} / \mathrm{hari}$ pada anak sapi bali jantan lepas sapih.

Lamtoro mengandung protein, kalsium dan energi yang tinggi . Menurut Jones (1979) dan Haryanto (1993), daun lamtoro mengandung protein yang relatif rendah tingkat pemecahannya di dalam rumen sehingga merupakan sumber protein yang baik untuk ternak ruminansia. Kandungan proteinnya berkisar antara 25 - 32\% dari bahan kering, sedangkan kalsium dan fosfomya berturut-turut antara 1,9-3,2\% dan 0,15-0,35\% dari bahan kering (Askar dkk ., 1997).

Kewajiban setiap Perguruan Tinggi sebagaimana dijelaskan dalam Tridharma Perguruan Tinggi adalah Pendidikan, Penelitian, dan Pengabdian Masyarakat. Melalui kegiatan pengabdian pada masyarakat diharapkan ilmu-ilmu dan teknologi terbaru mampu ditransfer dan diaplikasikan oleh masyarakat guna mengatasi masalah-masalah yang sering dihadapi sekaligus meningkatkan kesejahteraannya. Oleh karena itu, salah satu pengabdian pada masyarakat yang dilaksanakan oleh Tim Pengabdian kepada Masyarakat Fakultas Peternakan Laboratorium Nutrisi Ternak Ruminansia 
dan Herbivora adalah meberikan penyuluhan dan demonstrasi penanaman dan pemberian lamtoro sebagai pakan ternak, dengan mempertimbangkan mayoritas masyarakat Desa Penyaring Kecamatan Moyo Utara yang saat ini tengah menggeluti usaha peternakan, maka dipilihlah desa tersebut sebagai lokasi sasaran kegiatan pengabdian pada masyarakat.

Adapun tujuan dari kegiatan ini adalah untuk memberikan informasi kepada masyarakat secara langsung proses penanaman lamtoro taramba dan teknik pemberiannya pada ternak ruminansia serta manfaat dan keunggulan lamtoro taramba sebagai bahan pakan ternak.

\section{METODE}

Sasaran kegiatan pemberdayaan masyarakat melalui pemanfaatan lamtoro sebagai pakan ternak ini adalah Kelompok Peternak Maju Bersama Desa Penyaring Kecamatan Moyo Utara Kabupaten Sumbawa, yang saat ini tengah banyak menggeluti usaha ternak ruminansia. Kegiatan pengabdian bekerja sama dengan Kelompok Peternak Maju Bersama Desa Penyaring Kecamatan Moyo Utara Kabupaten Sumbawa dilakukan terutama dalam rangka mengidentifikasi masyarakat serta mengorganisir mereka untuk mengikuti kegiatan pengabdian tersebut. Selain itu kerjasama juga dimaksudkan untuk mengidentifikasi lokasi sebagai tempat penyuluhan, demonstrasi, dan pelatihan sebagai rangkaian kegiatan pengabdian ini.

Kegiatan dilaksanakan dengan metode ceramah, diskusi, dan demonstrasi. Secara lebih rinci materi yang akan disampaikan pada kegiatan penyuluhan ini dapat diuraikan sebagai berikut :

1. Manfaat Lamtoro sebagai tanaman reboisasi dan pakan ternak (Bank Pakan)

2. Nilai nutrisi lamtoro dan cara pemberian lamtoro sebagai pakan ternak

3. Teknik bududaya tanaman lamtoro.

\section{HASIL DAN PEMBAHASAN}

Dalam usaha peternakan, sekitar 60-70\% dari seluruh biaya produksi dialokasikan untuk penyediaan pakan. Ketersedian pakan yang selalu berfluktuatif juga mempengaruhi besar kecilnya biaya produksi. Salah satu faktor lingkungan yang sangat berpengaruh terhadap produktivitas ternak adalah pakan. Oleh karena itu, selain kandungan nutrisinya yang harus dipertahankan, kontinyuitas dari pakan juga perlu diperhatikan. Ketersediaan pakan yang umumnya sangat berlimpah pada musim hujan sedangkan sangat minim pada musim kemarau menyebabkan kualitas dan kuantitas pakan pada musim kemarau menurun cukup drastis. Ditambah lagi penyediaan pakan peternak yang masih sangat bergantung pada ketersedian rumput lapangan menyebabkan peternak harus berusaha ekstra untuk mendapatkan pakan pada musim kemarau.

Disisi lain, Desa Penyaring adalah daerah yang masyarakatnya lebih banyak bermata pencaharian sebagai petani peternak, maka tentu saja di daerah ini memerlukan ketersediaan hijauan pakan yang berkualitas sepanjang tahun dalam jumlah yang tidak sedikit mengingat populasi ternak yang dipelihara tidak sedikit terutama ternak ruminansia.

Topografi Kecamatan Moyo Utara tidak rata, karena daerahnya berbukit-bukit dan terdapat padang rumput yang cocok untuk peternakan. Dari total luas wilayah tersebut,hanya sekitar 24 persen dari total luas wilayah dijadikan lahan sawah sedangkan sisanya adalah lahan kering. Banyaknya lahan kering secara tidak langsung dipengaruhi pula dengan adanya faktor alam seperti iklim. Faktor iklim 
dan cuaca dapat dilihat dari besarnya curah hujan dan hari hujan yang cenderung menurun dibandingkan dengan beberapa tahun sebelumnya.

Pada pertanian lahan sempit, hampir semua lahan dipakai untuk tanaman pangan dan perkebunan, Tidak ada lahan khusus yang disediakan untuk menanam semak dan pohon. Pakan ternak tumbuh pada galangan, lahan tidur, pinggir jalan, lapangan dan lahan yang tidak dipakai untuk tanaman kebutuhan manusia. Masalah utama yang dihadapi oleh petani di lahan kering adalah tidak tersedianya secara khusus pakan hijauan untuk kebutuhan ternak sepanjang tahun.

Apabila ditinjau dari sub sektor peternakan, kedua permasalahan ini akan berdampak langsung pada peningkatan produktivitas ternak dalam kaitannya dengan penyediaan pakan karena sebagian besar pakan ternak khususnya ternak ruminansia terdiri dari hijauan. Untuk itu kontinyuitasnya harus terjaga sepanjang tahun. Untuk mengatasi masalah ini diperlukan suatu sistem penanaman hijauan pakan ternak sehingga dapat tersedia sepanjang tahun.

Kegiatan penyuluhan dilaksanakan pada tanggal 5 September 2020 melibatkan 20 orang peserta. Peserta terdiri dari berbagai kalangan termasuk didalamnya adalah para peternak sapi dan kambing. Kegiatan pengabdian dikemas dalam bentuk ceramah dan diskusi lalu dilanjutkan dengan demonstrasi dan pelatihan. Selain diberikan materi mengenai teknik budidaya tanaman, peserta juga diajarkan langsung bagaimana cara pemberian lamtoro sebagai salah satu jenis pakan.

Respon peternak terhadap kegiatan pengabdian ini terlihat cukup baik. Hal ini terlihat dari antusiasme para petani peternak dalam menerima materi yang diberikan serta keikutsertaan mereka dalam mempraktekan pemberian lamtoro sebagai pakan ternak yang dikombinasikan dengan jenis pakan lain. Selain itu petani peternak juga sangat aktif dalam berbagi pengalaman serta mengungkapkan masalah-masalah yang sering dihadapi selama bertani maupun beternak. Peserta juga berharap bahwa kegiatan-kegiatan yang praktis dan aplikatif diterapkan oleh masyarakat seperti ini harus sering dilakukan guna meningkatkan kecakapan mereka dalam bidang yang masing-masing mereka geluti. Berikut adalah beberapa gambar pada saat dilakukan kegiatan pengabdian.

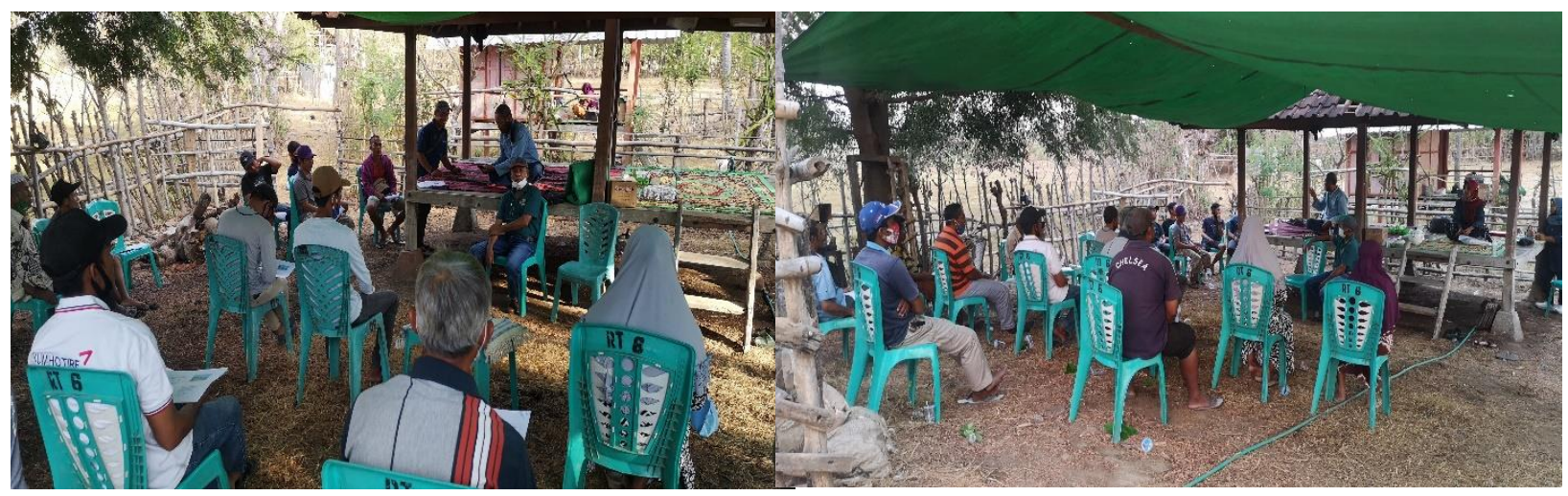

Gambar 1. Budidaya Lamtoro Sebagai Bank Pakan Sumber Protein 



Gambar 2. Pembersihan lahan dan pembibitan lamtoro

Hasil langsung dari kegiatan pengabdian yang dilakukan di Kelompok Ternak Maju Bersama Desa Penyaring Kabupaten Sumbawa terlihat dari antusiasme para peserta serta perubahan prilaku peternak yang mulai memanfaatkan lahan kering yang kurang termanfaatkan sebagai lahan pertenian seperti pematang lahan tidur disekitarnya untuk dijadikan tempat budidaya tanaman lamtoro serta memanfaatkan lahan pertanian yang kurang produktif sebagai tempat penanaman lamtoro secara tumpang sari dengan jenis tanaman pertanian lainnya seperti jagung. Masyarakat akhirnya sadar bahwa beternak dan bertani merupakan dua kegiatan yang dapat saling memberikan keuntungan. Masyarakat juga merasa sangat antusias karena akhirnya mereka mendapatkan pengetahuan bagaimana cara mengatasi masalah kekurangan pakan ketika musim kemarau dengan cara yang efektif dan efisien. Hal ini menunjukkan bahwa peternak mulai berpikir secara agribisnis dimana mereka memanfaatkan limbah untuk menunjang kegiatan produksi mereka tanpa mengeluarkan biaya besar.

Pembibitan lamtoro dapat dilakukan dengan beberapa cara, yakni dapat menggunakan biji, cabutan/stum, semaian dalam plastik polybag, stek, dan kultur jaringan. Berikut dikemukakan masing-masing cara menanam lamtoro dimaksud.

a. Menggunakan Biji

Menyemaikan lamtoro menggunakan biji dapat dilakukan dengan cara sebagai berikut:

- Biji hendaknya berasal dari pohon induk yang sudah agak tua yakni umur 15 tahun, berbatang lurus, bertajuk lebat, dan sehat. Kalau membeli benih, sebaiknya dibeli dari produsen benih yang mempunyai sertifikat. Di Indonesia, salah satu produsen benih hijauan makanan ternak adalah Balai Pembibitan Ternak dan Hijauan Makanan Ternak (BPTHMT) Serading Sumbawa - Nusa Tenggara Barat. Institusi ini memproduksi 22 macam benih hijauan makanan ternak.

- Biji yang diperoleh kemudian diseleksi untuk memilih yang baik. Ciri-ciri biji yang bagus adalah tidak berlubang, tenggelam bila direndam dalam air, ukuran biji seragam.

- Biji yang telah diseleksi tersebut diharapkan mempunyai daya kecambah $\geq 80 \%$.

b. Menggunakan Cabutan (Stum)

- Biji lamtoro ditanam di lahan yang telah dipersiapkan untuk itu

- Biji sebaiknya ditanam pada awal musim hujan atau ketika tanah masih basah/lembab

- Anakan dicabut secara hati-hati setelah tinggi tanaman mencapai $30 \mathrm{~cm}$ 
- Pencabutan dilakukan lurus sejajar batangnya dan diusahakan agar akarnya tidak putus

- Anakan yang telah dicabut hendaknya segera diangkut ke lokasi penanaman

- Pengangkutan diatur sedemikian rupa, disusun searah, akar dengan akar dan daun dengan daun.

c. Menggunakan Semaian dalam plastik polybag

Penyemaian bibit lamtoro dilakukan dalam plastik polybag dengan cara meletakkan 1-3 biji lamtoro. Setelah benih berumur 2 bulan atau tinggi benih mencapai $30 \mathrm{~cm}$, maka benih siap untuk dipindahkan ketempat penanaman. Sebelum dipindahkan untuk ditanam di padang penggembalaan, terlebih dahulu disiapkan campuran media tumbuh yang terdiri atas tanah: pupuk kandang: pasir dengan perbandingan 45:45:10.

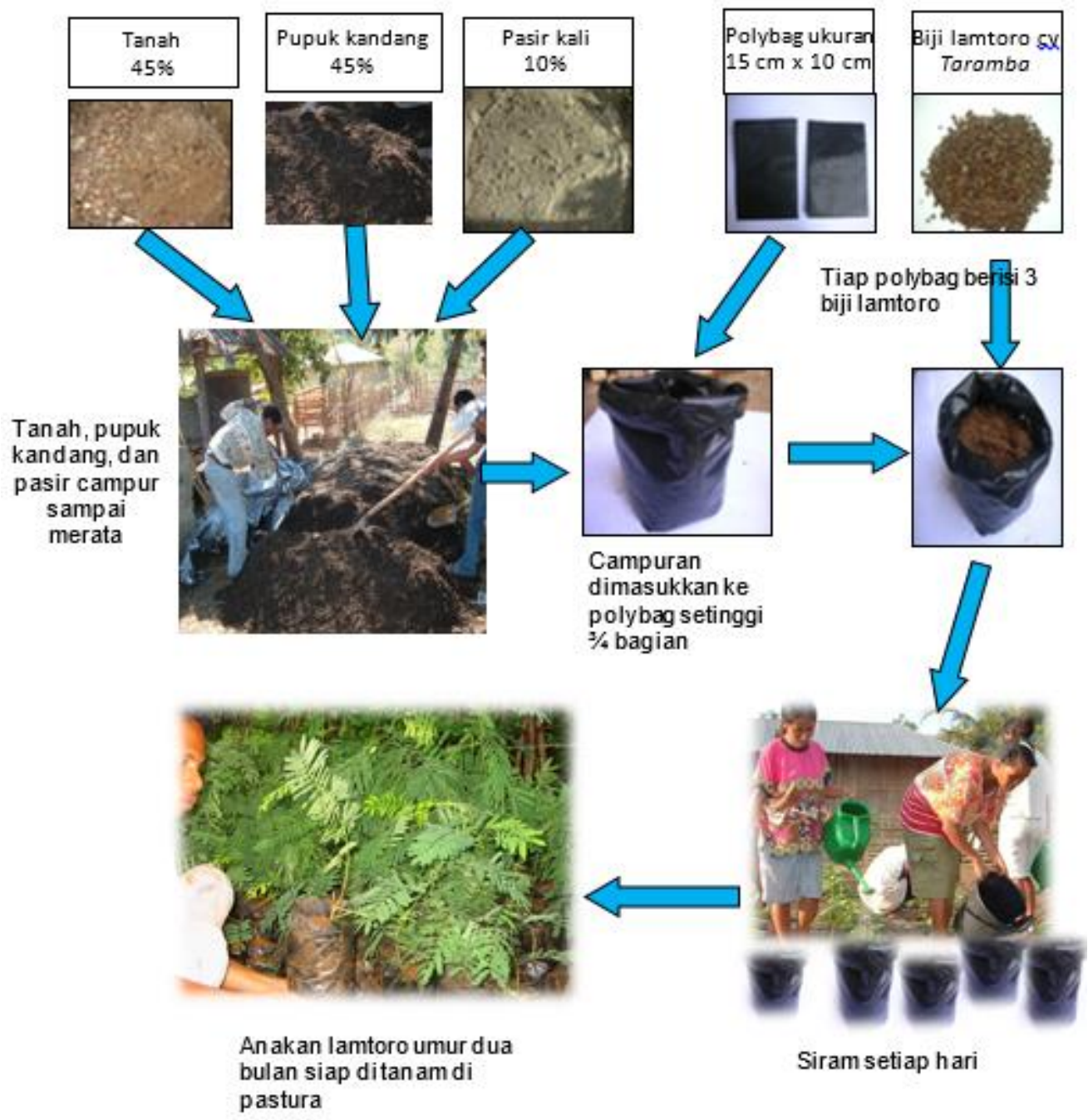

Gambar 3. Tatacara penyemaian lamtoro dalam plastik polybag (Dikutip dari

Dahlanuddin et al., 2014a).

Adapun cara melakukan penyemaian sebagai berikut:

1. Siapkan polybag ukuran $15 \times 10 \mathrm{~cm}$

2. Masukkan campuran media tumbuh kedalam polybag secukupnya 
3. Isi setiap polybag dengan 1-3 biji lamtoro

4. Siram secara teratur.

5. Tanaman dalam polybag sudah dapat dipindahkan untuk ditanam di padang rumput setelah berumur 60 hari.

6. Perkiraan bibit Lamtoro:

a. lamtoro ditanam menggunakan polybag. Setiap polybag berisi 3 batang bibit lamtoro,

b. kebutuhan bibit adalah sejumlah : 1500 polybag/Ha,

c. perkiraan kebutuhan biji Lamtoro adalah : 4500 x $90=405.000$ biji,

d. Jumlah biji $/ \mathrm{kg}$ lamtoro : $15.000 \mathrm{biji} / \mathrm{kg}$,

e. Perkiraan biji viable adalah $80 \%=80 / 100 \times 15.000=12.000 \mathrm{biji} / \mathrm{kg}$,

f. Kebutuhan biji lamtoro $=405.000 / 12.000=33.8 \mathrm{~kg}$.

d. Menggunakan Stek

Terlebih dahulu perlu dibuatkan bedeng kebun pangkas

1. Ukuran bedeng (1.5-2 meter) x 6 meter dengan arah utara-selatan dan jarak antar bedeng 0.6 meter. Di sekeliling bedeng perlu dibuatkan penahan dari papan dengan tinggi $\pm 15 \mathrm{~cm}$ dari permukaan tanah

2. Setiap bedeng agar diberi atap supaya bibit terlindung dari matahari dan air hujan secara langsung. Penahan bedeng sebaiknya terbuat dari bahan yang tahan lama, kemudian diisi campuran media setinggi $\pm 20 \mathrm{~cm}$.

3. Media yang digunakan untuk kebun pangkas adalah campuran top soil, sekam, gambut dengan perbandingan 6:3:1.

4. Perbandingan antara luas lahan untuk keperluan jalan inspeksi dengan luas bedengan adalah 1 $: 3$

5. Bahan tanaman kebun pangkas sebaiknya bibit-bibit vegetatif atau bibit dari biji yang berasal dari pohon induk yang fenotipnya bagus.

\section{- Pembuatan stek}

1. Bahan stek diambil dari anakan yang berasal dari kebun pangkas harus bersifat juvenille atau muda dan tunas autotrop bukan cabang. Untuk tahap pertama tiap bibit dapat menghasilkan \pm 14 stek.

2. Untuk meningkatkan mutu bibit stek yang dihasilkan dari kebun pangkas, dianjurkan lagi untuk digunakan sebagai bahan pembuatan kebun pangkas. Dipilih bibit yang pertumbuhannya seragam baik fungsi maupun jumlah daunnya.

3. Ukuran bak stek dengan media padat dan media air (water rooting system) adalah $1 \times 2$ meter dengan tinggi $0.6 \mathrm{~m}$. Dalam rangka menstabilkan suhu media konstruksi bak stek agar dibuat dengan dinding beton selebar $\pm 10 \mathrm{Cm}$

4. Naungan perlu diberikan supaya intensitas cahaya yang masuk kedalam stek tidak terlalu tinggi (optimum 50\%). Untuk penaungan ini dapat digunakan plastik transparan berwarna putih.

5. Jarak tanam bak stek $5 \times 5 \mathrm{Cm}$.

6. Bahan vegetatif tanaman (tunas pucuk) untuk pembuatan stek pucuk dapat diperoleh dari beberapa sumber seperti kebun pangkas, persemaian (pemangkasan bergulir), dan semai alami. 
e. Menggunakan Kultur Jaringan

- Memilih dan menyiapkan tanaman induk sebagai sumber eksplan

- Menyiapkan media kultur

- Sterilisasi eksplan

- Inisiasi kultur atau culture establishment

- Multiplikasi atau perbanyakan propagasi (bahan tanaman yang diperbanyak seperti tunas atau embrio)

- Pemanjangan tunas induksi dan perkembangan akar

- Aklimatisasi ke lingkungan eksternal (green house)

Demikian beberapa cara pembibitan dan penanaman lamtoro. Cara mana yang dipilih sangat tergantung pada tujuan penanaman lamtoro, fasilitas yang tersedia, dan luas lahan. Setelah penanaman dilakukan, maka langkah berikut yang penting untuk diperhatikan adalah bagaimana mengelola tanaman tersebut agar mencapai daya guna maksimal.

\section{Merawat Tanaman Lamtoro}

Perawatan tanaman lamtoro meliputi penyiraman, pemupukan, penyulaman, pengendalian hama dan penyakit tanaman.

Penyiraman tanaman lamtoro hendaknya dilakukan dengan hati-hati agar tanaman tidak rusak, baik daun maupun batangnya. Jika media tanamnya mudah kering, maka frekuensi penyiraman sebaiknya dua kali sehari, yaitu pagi dan sore. Jika media tanamnya cenderung lembab, maka penyiraman cukup dilakukan satu kali sehari, pagi atau sore. Sebaiknya tidak melakukan penyiraman di siang hari, karena dapat menimbulkan kelayuan pada tanaman.

Pemupukan tanaman lamtoro dilakukan dengan dosis dan cara penggunaan pupuk yang disesuaikan dengan petunjuk pada kemasan masing-masing pupuk.

Bila bibit tanaman lamtoro tumbuh tidak sempurna atau rusak atau mati, maka segera lakukan penyulaman (tanam kembali) dengan bibit Lamtoro lainnya (jika ada). Bila di sekitar tanaman Lamtoro tumbuh gulma, maka lakukan penyiangan dengan mencabuti gulma tersebut, juga sekaligus gemburkan tanah di sekitar tanaman.

Lakukan pembumbunan pada tanaman lamtoro, terutama jika tanah disekitar tanaman mulai tergerus, atau ada akar tanaman yang muncul kepermukaan tanah. Juga ketika tanaman tumbuhnya agak miring (tidak tegak).

\section{Pengendalian Hama Tanaman.}

- Hama tanaman antara lain trips, kutu daun, tungau, kutu kebul, ulat gerayak, dan sebagainya. Peluang munculnya hama tanaman ini akan semakin tinggi pada musim kemarau.

- Bila satu tanaman terkena hama dan dibiarkan, maka dengan cepat tanaman lainnya juga terkena hama tersebut, sehingga harus dibasmi.

- Untuk mengatasi hal tersebut, lakukan pengendalian dengan cara menyemprotkan insektisida untuk hama serangga dan akarisida untuk tungau, setiap minggu sesuai dosis, jika diperlukan.

\section{Pengendalian Penyakit Tanaman.}

- Penyakit tanaman antara lain rebah kecambah, layu bakteri, layu (fusarium), antraknosa, busuk daun (choanephora), hawar phytophora, bercak daun (cercospora), bercak bakteri, busuk lunak 
bakteri, keriting kuning, dsb. Serangan penyakit tertentu yang disebabkan oleh cendawan dan bakteri akan semakin tinggi pada musin hujan.

- Seperti halnya dengan hama, bila satu tanaman terkena penyakit dan dibiarkan, maka dengan cepat tanaman lainnya juga terkena penyakit tersebut, sehingga jangan dibiarkan.

Untuk mengatasi hal tersebut, lakukan pengendalian dengan cara menyemprotkan fungisida setiap minggu sesuai dosis, jika diperlukan. Petunjuk dosisnya terdapat pada kemasan fungisida terkait.

\section{KESIMPULAN DAN SARAN}

\section{Kesimpulan}

Kesimpulan yang dapat ditarik dari kegiatan pengabdian ini adalah :

1. Kelompok Tani Ternak Maju bersama Desa Penyaring Kecamatan Moyo Utara sudah mulai memahami teknik membudidayakan lamtoro sebagai bank pakan sumber Protein bagi ternak ruminansia.

2. Kurangnya informasi, pemahaman, dan kesadaran peternak memanfaatkan lahan tidak produktif sebagai tempat budidaya lamtoro sebagai bank pakan sumber protein merupakan salah satu kendala minimnya ketersediaan hijauan pakan di desa penyaring pada musim kemarau.

\section{Saran}

Perlu adanya pendampingan secara kontinyu untuk memastikan apa yang telah disuluhkan dapat diterapkan dalam pengembangan peternakan selanjutnya.

\section{Ucapan Terima Kasih}

Terima kasih yang sebesar besarnya kami sampaiakan kepada Rektor Universitas Mataram dan Lembaga Penelitian dan Pengabdian Kepada Masyarakat atas dukungan dana dalam pelaksanaan kegiatan ini, serta semua pihak yang secara langsung maupun tidak langsung membantu kelancaran pelaksanaan pengabdian ini.

\section{DAFTAR PUSTAKA}

Askar, S. dan Nina Marlina. 1997. Komposisi kimia beberapa hijauan pakan. Bulletin Teknik Pertanian: 2 (1):7-11.

DahlanuddinA, O. Yanuariantoo, D. P. PoppiB, S. R. McLennanc and S. P. QuigleyB'D. (2014) Liveweight gain and feed intake of weaned Bali cattle fed grass and tree legumes in West Nusa Tenggara, Indonesia. Animal Production Science, CSIRO PUBLISHING. 54, 91 5-921

Dilaga S. H., Imran, S. Nurlaili.,Padusung, 2016. Lamtoro Sumber Pakan Potensial. Pustaka Reka Cipta.

Haryanto, B. dan A. Djajanegara. 1993. Pemenuhan kebutuhan zat-zat makanan ternak ruminansia kecil. Sebelas Maret University Press. Hal 192-194.

Jones, R.J. 1979. The value of Leucaena leucocephala as a feed for ruminants in tropics. World Anim. Rev., No. 31. Hal 13-23.

Zulakrnaen, 2019. Budidaya Tanaman Lantoro Sebagai Sumbar Pakan Ternak. http://cybex.pertanian.go.id/mobile/artikel/80562/Budidaya-Tanaman-Lantoro-SebagaiSumbar-Pakan-Ternak/ 